The Journal of Peasant Studies

\title{
Populism from above and below: the path to regression in Brazil
}

\section{Daniela Andrade}

To cite this article: Daniela Andrade (2019): Populism from above and below: the path to regression in Brazil, The Journal of Peasant Studies, DOI: 10.1080/03066150.2019.1680542

To link to this article: https://doi.org/10.1080/03066150.2019.1680542
(c) 2019 The Author(s). Published by Informa UK Limited, trading as Taylor \& Francis Group
曲 Published online: 18 Nov 2019.
Submit your article to this journal $₫$

Q View related articles $\asymp$

View Crossmark data $₫$ 


\title{
Populism from above and below: the path to regression in Brazil
}

\author{
Daniela Andrade \\ International Institute of Social Studies (ISS), The Hague, the Netherlands
}

\begin{abstract}
Brazil has recently shifted from economic growth to recession, from left-wing to far-right politics and from neo-developmentalist to ultra-liberal economic policies. This regressive change in Brazil (and elsewhere) has prompted the need for empirical investigation and emancipatory movement-building, as urged by the Emancipatory Rural Politics Initiative (ERPI). This article responds to the ERPI call by reflecting on the politics of the past. It argues that the road to regression was paved during the tenure of the Workers' Party, when Lula's leadership emerged as representative of interests 'from below' while advancing a political project that protected and nurtured interests 'from above' - a populist ambiguity. By offering an understanding from a class political economy perspective, this article concludes that reinforcing left-wing populism in the face of authoritarianism is unlikely to create a path to emancipation.
\end{abstract}

\section{KEYWORDS}

Brazil; Lulism; populism; neodevelopmentalism; neoliberalism; agribusiness

\section{Introduction}

The Emancipatory Rural Politics Initiative (ERPI), launched in October 2017 by a group of scholars, echoed growing concern over the rise of populist governments around the world, many of which are associated with authoritarian, right-wing and exclusionary politics. In the ERPI framing article, Scoones et al. (2018) make 'authoritarian populism' their primary focus and specify the 'rural world' as the site of their scholarly efforts. As the authors point out, the rural setting has served as both an electoral base for populist leaders and a base for resistance and alternative politics. They argue that the spread of authoritarian populism is not only a reason for concern, but also a call for emancipatory rural politics. Seeking to grasp a better understanding of populism and its authoritarian form, the ERPI has called on scholars to provide insights from their countries of study by considering whether and how the rural context is affected by, contributes, or reacts to populism.

Editorial Note: This paper is part of the 'JPS Forum on Authoritarian Populism and the Rural World', framed and introduced by lan Scoones and colleagues in their joint paper, 'Emancipatory Rural Politics: Confronting Authoritarian Populism', published in JPS in January 2018. The contributions to this forum will be published separately and in clusters in 2018 and 2019. This forum is one of the initial outcomes of the activities of the Emancipatory Rural Politics Initiative (ERPI, www.iss.nl/erpi).

CONTACT Daniela Andrade $\otimes$ andrade@iss.nl $\Theta$ International Institute of Social Studies (ISS), Kortenaerkade 12, 2518AX The Hague, the Netherlands

(c) 2019 The Author(s). Published by Informa UK Limited, trading as Taylor \& Francis Group

This is an Open Access article distributed under the terms of the Creative Commons Attribution-NonCommercial-NoDerivatives License (http://creativecommons.org/licenses/by-nc-nd/4.0/), which permits non-commercial re-use, distribution, and reproduction in any medium, provided the original work is properly cited, and is not altered, transformed, or built upon in any way. 
This article focuses on Brazil, a country where the economic and political tide has recently changed. In 2016, Brazil entered a full-blown recession and underwent a hostile impeachment process fueled by a popular uprising that brought to an end not only the mandate of democratically elected president Dilma Rousseff, but also a 13-year period (2003-2016) during which the Workers' Party (Partido dos Trabalhadores, PT) was in power. After the impeachment process, policies shifted toward stark economic austerity and the curtailment of labor rights. Such an authoritarian and reactionary U-turn was consolidated in October 2018 with the election of former military officer and congressman Jair Bolsonaro, who openly espoused dictatorial principles, moral conservatism and ultra-economic liberalism. Fear, hate and hope, mobilized by a vicious presidential campaign, boosted his political ascension. All of the above suggest that Brazil has joined the club of right-wing authoritarian populist governments - a setback that has reached the countryside, and in contrasting ways.

It should be noted that $50 \%$ of the impeachment votes in the Chamber of Deputies were cast by the so-called Agribusiness Parliamentary Front, which comprised $41 \%$ of the total number of serving parliamentarians (Castilho 2017). Still in 2016, this agribusiness caucus voted to shelve a corruption complaint lodged against interim president Michel Temer, saving his mandate. In exchange for their congressional vote, Temer's government committedly fulfilled the agribusiness sector's demands (Castilho 2017).

By contrast, the 'family farm' sector quickly started to experience the bitter effects of authoritarianism and austerity, including direct violence. In its first week in power, the interim government abolished the Ministry of Agrarian Development and eliminated or severely reduced internationally celebrated programs that were providing support and welfare to the rural poor, such as the Bolsa Familia or the Food Acquisition Program (PAA), among several other setbacks (see e.g. Pericás 2017 and Mitidiero Junior 2018). Perhaps even more alarming was the sharp increase in the number of murders, death threats, murder attempts, instances of torture and imprisonment of rural peoples since the impeachment (CPT 2017). ${ }^{1}$

In face of this political throwback and the quickly deteriorating economic and social conditions in rural areas, agrarian movements and other organized social forces have been confronted with the pressing need to mobilize the masses to contest the drastic cutbacks in public support, as well as to reclaim the loss of political representation in the government. As part of that endeavor, from August 2017 to March 2018, the Landless Workers' Movement (Movimento dos Trabalhadores Sem Terra, MST) openly supported former president Luiz Inácio Lula da Silva (Lula, for the PT) during a pre-presidential election caravan that took place across the country. At the time, Lula was the PT's official candidate and topped all opinion polls.

Together, these elements place Brazil at the center of the ERPI problematic, yet with a caveat: the risk that scholarship as well as resistance and mobilization - which together form the primary foci of the ERPI - would focus on recent political changes without sufficient reflection on and learning from the politics of the past. This becomes imperative given the suspicion that the road to regression did not start with the ousting of Rousseff, but was paved during the PT's tenure, when the government enjoyed popular support and

\footnotetext{
${ }^{1}$ Between 2016 and 2017, 132 rural dwellers, many of whom in leadership positions, were murdered - a 100\% increase in the average number of murders per year compared with the 2005-2014 period (CPT 2017).
} 
its politics were celebrated for promoting a post-neoliberal and neo-developmentalist project that primarily affected the poor (see Sader 2013). Notably, the rural context was central to the PT's politics. It was not due to misfortune or mere coincidence, but rather to critical political choices that Lula's project was shipwrecked just after the end of the global commodity boom.

Agricultural production and exports, which have undergone widespread expansion since the early 2000s, have played a crucial albeit ambiguous role in the politics of the PT. These were instrumental in bringing back economic stability and growth, enabling the state to sponsor a new type of economic and social progress, which was central in giving rise to and propelling the phenomenon of 'Lulism' (Singer 2009): the identification of Lula as representative of interests 'from below'. Yet agricultural exports were also structural to a state-sponsored pattern of accumulation 'from above', clashing with the PT's claim of promoting a popular political project. The countryside became the backdrop for strategy contradictions that placed the very poor in alliance with the dominant classes. The mystification of this ambiguous form by which the PT secured and exerted power, and represented the interests of its social base, is characteristic of populism.

This phenomenon needs to be carefully understood so that its constitutive flaws and political consequences can be fully exposed and confronted. The first section of this article presents an understanding of populism in light of the class-based political economy; this creates the foundations for the ensuing analysis of Lulism and the PT's politics in three stages. The first stage describes the way in which politics was perceived by the people and how this shaped political outcomes. The second stage examines the economic and social bases of politics, contrasting apparent and concrete social effects. In the final stage, the article reflects on Lula's model of populism to shed light on the recent regressive turn and inform emancipatory politics.

\section{Approaching populism}

[...] if social and political aspirations are not disciplined by careful theory and analysis, they will lead to false prescription and to development policies which fail. Theory is not therefore a mere intellectual indulgence, but, at its best, the most 'practical' of activities. (Kitching 1989, 5)

Since the end of the 1990s and throughout the 2000s, several left-leaning governments in Latin America have surfed the commodity boom wave, promoting economic growth and social development (Vergara-Camus and Kay 2017). The so-called 'Pink Tide' governments, notably those in Ecuador, Bolivia and Venezuela, have been associated with left-wing or neo-populism (de la Torre 2016; Andreucci 2017), and in a positive fashion. Echoing such an assessment, Scoones et al. $(2018,3)$ note that neo-populist governments in the region have been in favor of 'the people', once achieving 'impressive gains in poverty reduction and expanded political recognition and government support for previously marginalised groups'. Their interpretation seems to imply that populism, as long as it is not right-wing and authoritarian, becomes a desirable feature of politics. It is unclear, however, what is meant by the term populism itself. Certainly, not all popular and progressive politics are populist, just as not all populist politics are progressive. The same applies to authoritarian, right-wing, xenophobic or other sorts of (populist) politics.

Drawing from Kitching's opening quote, defining and analyzing populism should not be a mere intellectual indulgence, but rather a practical activity with important political 
consequences. Even though this article is not the space for extensive theoretical exploration, key conceptual aspects of populism should be reflected upon so that real experiences can be singled out and direct effects exposed. Contrary to the Pink Tide governments mentioned above, the Brazilian government has seldom been associated with populism, even if also being at the forefront of extractivism and neo-developmentalism.

So, what is populism? Why would the PT government, under Lula's leadership, make a case for it? And why does this analysis matter? In light of the political economy, populism is a political phenomenon and, as such, is entrenched in and unfolds into economic and social phenomena, all of which must be reflected upon in the analysis. When conceptualizing populism, it is essential that questions such as who controls what, who does what and who gets what are addressed theoretically.

\section{The political economy of populism}

\section{Democratic representation as a system of power, with populism as its fetish}

The events of authoritarian populism that the ERPI is concerned with emerged between the cracks of representative democracy - the formal governing system of most capitalist economies, including Brazil. Populism is rooted in relations of representation, which, in the context discussed here, are those between the state (as the representative) and citizens (as the represented).

In a system of representative democracy, citizens have the power to elect (or reject) a government through voting, which not only is a limited way of expressing preferences and demands, but also has a limited scope for participation in decision-making. State representatives are the ones who can effectively express, and decide how to implement, views on public matters. An inevitable disposition of power therefore underlies political representation because of differences in agency and the decision-making capacities of those with concrete needs, interests and demands, and those who voice and realize them on their behalf.

It is therefore important to observe the political roles played by state agency and decision-making power in representing societies whose social organization is based on the monopoly of the means of production by a minority and wage employment of the majority - the basis of the compulsion to purchase labor power (for commodity production for profit) and sell labor power (for material and social reproduction) (Fine and Saad-Filho 2016). This means that, when governing, the state inevitably confronts social interests arising from the (class) position of different groups within capitalist social divisions. State policies will represent, protect and nurture particular social interests while simultaneously remediating, neglecting or undermining others.

State political choices therefore express a class character, whereas maintaining political control of the state denotes the political power of a class over the economy and society. The state's political choices are conditioned by and reflect social disputes over the (re)organization of property, as well as the processes of production, appropriation and accumulation. This is why Wood argues that the state represents the ultimate locus of social force; it is 'the decisive point of concentration for all power in society' $(1995,47)$.

As she rightly points out, even if ensuring the right to vote for all citizens (regardless of socioeconomic position), the system of representative democracy has been opportune for 
maintaining the capitalist social order. Exerting 'civic freedom and equality' $(1995,201)$ does not directly affect the logic (and legitimacy) of private property, market compulsion and the profit maximization imperative forming the capitalist spheres of domination and coercion $(1995,234)$. Even though democracy in its original and historical sense denotes rule by the demos, "the people", representative democracy conceals and legitimizes rule by the dominant (propertied) classes (Wood 1995).

When embedded in state and society relations, populism further conceals the flaws of representative democracy while concurrently exacerbating them. As a corollary, democracy as a whole is perceived to be more transparent, direct, legitimate and just while becoming more arbitrary, personalistic and pernicious to the working class. Unsurprisingly, populist leaders produce deep loyalties and cleavages, polarizing 'their polities and the academic community into those who regarded them as democratic innovators, and those who considered them a threat to democracy' (de la Torre 2017, 195). These tensions have been evidenced in the recent debates on the 'Pink Tide' in Latin America. The next section explains how populism affects political representation in democratic capitalist societies as a way of expanding the view introduced here.

\section{Fetishism and ambiguous politics}

What becomes distinctive in relations of representation when populism is embedded, and what is particular to the manifestation of populism itself, is the existence of a fetish: the fetish of a genuine popular democratic representation, or even of popular power. Drawing upon Marx's fetishism of the commodity (1992 [1867], Vol. 1, Chapter 1), fetishism is understood as a social perception or a collective construct of social reality (needs, identity, rights etc.), which is formed, on the one hand, from concrete social experiences of people, thereby corresponding to materiality. Yet, on the other hand, it is a perception that obscures, misrepresents and ultimately conflicts with more fundamental aspects of that same social reality at the abstract level - that of social (class) relations. Fetishism is the mystification of social relations, but it is not simply a false or illusory perception of reality, or a phenomenon happening only in people's minds; it is first and foremost a practical phenomenon expressing ideas that correspond to (and shape) concrete forms of appearance of social reality. As such, a fetish is social and historically determined.

Populism is fetishized politics of people's representation, and thus associated with the fetish of 'the people', the 'common good', 'popular will' or general welfare. The fetishization of social matters may prompt discursive, ideological and social unity (mystifying class and other social divisions). By default, fetishized social unity creates an equally mystified social 'other'. Social polarization is part of populism, as are changes in the social correlation of forces and power relations.

In a democratic political system, populism often leads to the seizure of the state, expansion and reproduction of the political power of social representation. A state representative becomes the direct voice of 'the people' and the agent that realizes the popular will. Populism creates leaders (usually male) who are often seen as a 'savior', a 'father', a 'hero' or 'one of us', embodying the collective identity or will (Arditi 2005, 81-83). A fetishized representative has greater public appeal not only as a matter of degree, but also quality. Personal charisma or background, cultural or partisan identity, and rhetorical or 
discursive devices can reinforce the fetish of representation. These factors help populist leaders to create a direct, unmediated, uninstitutionalized and quasi-personal relation with the constituencies they claim to represent (Weyland 2001, 14).

Laclau, who remains influential in the academic debate on populism, associates this phenomenon with a crisis of hegemonic power. However, drawing from a particular understanding of Gramsci, he circumscribes power and political hegemony to the spheres of discursive and ideological dominance (Laclau 1977), thus taking a partial view on the capitalist forms of domination. A dominant class exerts hegemony through the neutralization of potential resistance or conflicting ideologies of the dominated by articulating some of their views, discourses and demands (1977, 161-62). That way, he conceives of a 'populism of the dominated' $(1977,173-74)$ when the masses absorb and articulate a popular ideology of their own, thereby challenging, antagonizing and possibly overtaking the elite ideological hegemony. For Laclau, this would be not only desirable, but also necessary to put an alternative political project in place. ${ }^{2}$

The idea of 'people's power' detached from careful theorization can easily become an unproblematic treatment of transformative politics, which is an important aspect of populism itself. First, one should not assume the immediate interest of 'the people' (or the dominated) in defying the capitalist logic of social organization and inherent forms of oppression, differentiation and inequality (Wood 1995). Second, one should be suspicious of transformative politics arising from arbitrary popular unity, subjectively construed.

Third, one should be skeptical of the pursuit of transformative politics through political representation - 'won by proxy or conferred by benefaction' $(1995,103)$ - instead of through direct collective activity. Yet the populist fetish stalls people's protagonism and disempowers citizens. People become loyal to and reliant on a leadership that they entrust to act on their behalf, thereby widening the gap in agency and decision-making capacities between citizens and state representatives. Promoting social benefits, a populist leader favors the formation of a grateful and obedient mass (Lefort as mentioned in Arditi 2005, 96-97) instead of a critical, politically engaged and combative mass.

Finally, if progressive populism brings people's voices, material aspirations and ideologies to the political stage, and possibly to the top of the political system - thereby overtaking elite hegemony, as in Laclau's view - how does this correspond to the transformation of the (capitalist) patterns of property organization, production, distribution and appropriation? This is the crux of the matter. An ideological ascendancy of the dominated over the state's politics is populist when (and because) it is detached from a correspondent structural transformation on the control of property and market relations, which are the material forms of domination - and the most tangible ones. ${ }^{3}$

Populism makes all the more ambiguous who controls politics, who expresses their will, who drives the political project, who has agency, who holds power, who benefits and who loses. This political ambiguity, with a clear class connotation, forms the backbone of populist politics. As the term 'populism' indicates, this ambiguity is defined in relation to, and from the perspective of, the working class, which is both an agent of the state's political empowerment and a recipient of the state's political decisions. Populism does not enhance

\footnotetext{
${ }^{2}$ For Laclau (1977), socialist ideology is populist in nature. 'Socialist populism', therefore, is not backward, but rather the most advanced form of 'populism of the dominated'.

${ }^{3}$ In the case of progressive and possibly emancipatory politics, the political project, its practice and effects cohere - the antagonism is found in the very class struggle, transforming social and power relations.
} 
working-class agency and decision-making power, nor does it guarantee economic democracy or lead to social emancipation, even though this might appear to be the case.

Grasping the populist fetish requires two levels of analysis. One describes how a leader, social groups and the political agenda are perceived (as 'the people' against 'the elite', for example), and how their relationships, actions and political capacities are shaped as a result. Most descriptions and analyses of populism do just that, which is not unimportant; populism is about perceptions driving political outcomes and playing a key role in the battle for power. A judicious investigation, however, should take a second analytical step to disclose the relationship between the way reality is perceived and the way it is in essence - a task to which a Marxist political economy analysis is devoted (see Fine and Saad-Filho 2016, 4). The analysis should reveal how subjective, fetishized political relationships, such as those among 'the people' or between them and the state and its leaders, correspond objectively as social class relations. Assuming a macro perspective, this article explores broad class relations constituted and conditioned by a state-sponsored pattern of accumulation and development.

\section{3-2006: the making of a leader of the poor}

Brazil, a country for all

(2002 electoral campaign slogan)

Lula contested three presidential elections as a candidate for the PT before he was successful in 2002. Between his first electoral campaign in 1989 and his first term of office, Brazil underwent two mutually reinforcing and constituting transitions (Saad-Filho 2010, 24). The first was a political transition from 20 years of military dictatorship to an era of representative democracy. The second was an economic transition from developmentalism, supported by Import Substitution Industrialization (ISI) policies, to neoliberalism, underpinned by policy and institutional reforms in the early 1990s.

A combination of high interest rates, an overvalued currency, fiscal austerity measures, the privatization of public assets, open trade and capital borders - the cornerstones of the 1990s reforms - transformed the patterns of production, capital accumulation and labor reproduction in the country through a fast-advancing financialization process. The national industrial sector, once the pillar of the developmentalist model, was significantly harmed and with it the industrial workforce; more than two million salaried posts were lost between 1989 and 1999 in the industrial sector alone (Oliveira 2006, 11). In addition to this development, wages depreciated and labor rights were relaxed. As Saad-Filho (2010) remarks, democracy facilitated and legitimized economic changes that fragmented the labor force, repressed trade union activities and increased economic insecurity while creating the conditions for capital accumulation through the expansion and intensification of financial transactions that transferred income (and power) to the financial system. ${ }^{4}$

The new development pattern produced five years of macroeconomic stability and consumption-led growth (1993-1997), followed by five years of multiple crises and a recession (1998-2002), including a balance of payments crisis, currency collapse, the

\footnotetext{
${ }^{4}$ Saad-Filho $(2010,24)$ argues that democracy was established as 'the political form of neoliberalism in Brazil'. From 1989 onwards, the control and coercion of the working class become 'primarily "economic" rather than "political", as was the case under the dictatorship' (Saad-Filho 2010).
} 
return of inflation, further job cuts and the deterioration of public services. Lula obtained his first electoral triumph on the backdrop of crises - largely blamed on Cardoso's government. His electoral victory also reflected the PT's historical representation of the organized working class struggles, as well as contestations of the neoliberal ruling order. ${ }^{5}$

Lula was elected after securing $61.3 \%$ of the vote in the second (runoff) voting round, after having won $46.5 \%$ in the first. His votes originated from the social sectors most affected by the neoliberal financialization process. This group of voters, which SaadFilho and Morais $(2018,109-113)$ refer to as an 'alliance of losers', was composed of the unionized working class (rural and urban), civil servants, sections of the middle-class population and members of the business community (Saad-Filho and Morais 2018). They were predominantly educated, had higher levels of income, and resided in the most urbanized and industrialized states in the South and Southeast regions (Hunter and Power 2007, 4).

Although his election was celebrated as signifying the long-awaited 'rise of the left', Lula's electoral campaign showed that the PT no longer had the same political and ideological character of the past. The party had toned down its political discourse and adopted a non-confrontational spirit, encapsulated in its all-embracing 'Brazil for all' campaign slogan and in Lula's self-designation as the candidate of 'peace and love'. The party also allied with a center-right party, from which an industrial businessperson was handpicked for the post of vice president. In addition, near the campaign's final stage, Lula addressed the Brazilian people in a letter in which he vowed, if elected, to maintain the orthodox macroeconomic policies of his predecessor - a move considered both pragmatic and politically opportunistic.

Preceding the election, the Brazilian economy was on the verge of collapse, provoked by massive capital flight and domestic currency devaluation. Lula's letter was written in an attempt to appease nervous foreign investors - and the market in general - alarmed by his imminent election. It also served to gain the sympathy of more conservative constituents who had never voted for the PT. As Anderson (2011) noted, Lula had understood that 'it was not just builders and bankers who needed reassurance that he would not do anything unduly radical in power, but - even more crucially - street vendors and slum-dwellers too'.

In brief, Lula's campaign had an ambiguous political identity. Despite creating a glimmer of hope that improvements and political change would follow, it also produced a sense of political disenchantment and skepticism among the radical left and the PT's most politicized base. It was clear that the party had no mandate to carry on the structural changes that once formed its political agenda (Saad-Filho and Morais 2018, 116-117).

In January 2003, when Lula took office, the country was in disarray. Unexpectedly, however, by the end of his first year on the job, he had managed to stabilize the economy. From there, he continued to make steady gains throughout his term of office. In 2006, the year in which Lula was reelected, the country seemed to be ready to 'take off' - the Brazilian miracle was within reach!

Before understanding the basis for and the reach of his administration's economic and social achievements, the next section examines the appeal these achievements have effected - perhaps Lula's most significant political feat.

\footnotetext{
${ }^{5}$ Together with the Workers' Central Union (Central Única dos Trabalhadores, CUT), the PT has fought against 'privatizations, outsourcing and the managerial state model. At the same time, they have defended the universalization of public social policies and the state's responsibility to meet social needs' (Sitcovsky 2013, 119, author's translation).
} 


\section{Lulism}

Lula again, with the power of the people

(2006 electoral campaign slogan)

In 2006, Lula was reelected with $61 \%$ of the vote in the second voting round (having secured $48.6 \%$ in the first), thereby practically replicating the outcome of the 2002 elections. Yet the overall electoral result concealed a phenomenon that Brazilian intellectual André Singer termed 'Lulism': Lula's rise as a 'leader of the poor'. Lula was rejected by his previous electorate, but was reappointed as president by the vote of a new constituency with very different social features. ${ }^{6}$

Lula's new supporters included the internal bourgeoisie but especially the low and very low-income strata, beneficiaries of the social policies of his first mandate. This time, his constituency formed an 'alliance of winners' (Saad-Filho and Morais 2018, 126). The majority of Lula's voters encompassed a social category that Singer (2009) called the 'sub-proletariat"; ; they represented the Brazilian workforce majority since the period of neoliberal restructuring (Oliveira 2006, 11), consisting of mainly informal (irregular and unskilled) workers associated with precarious working conditions and poor remuneration - the working poor. These voters came from rural areas and overwhelmingly from the North and Northeast regions of the country.

For the first time in Brazilian history, the very poor voted for a candidate representing the left (Singer 2009, 90). Singer's explanation of the change in the voting pattern of the sub-proletariat is important to this article's argument. For him, this change reflected two characteristics of this social stratum that were met by Lula's inaugural legacy. First, given their poverty, this group had an objective and pressing need for material and social change. Second, and paradoxically, the sub-proletariat, even though desiring change, had a conservative political and moral ethos. Differing from the formal working class, these workers had no protection from unions or their own forms of labor organization, and had little capacity to build it from below (Singer 2009, 87-88); consequently, they were the most affected by strikes or social unrest, for example. As a result, this materially and socially vulnerable group desired change, but largely expected it without political confrontations or social distress. In fact, given their lack of social and political organization, they relied on the state to realize change and provide protection. In the 2006 election, they identified Lula as the leader of such a state who would tackle poverty and inequality without breaking from the established order.

As mentioned above, the PT adopted a non-confrontational strategy in the 2002 campaign, renouncing its radical leftist identity and moderating its discourse and political program. Singer $(2009,99)$ suggests that, unable to mobilize and shape the sub-proletariat

\footnotetext{
${ }^{6}$ The loss of the previous electorate's support is partially explained by the so-called 'mensalão' corruption scandal that erupted in 2005. Oliveira $(2006,5)$ also reminds us that, although voting is compulsory in Brazil, $31 \%$ of the electorate either did not vote or cast blank or null votes - the highest rate of electoral indifference in Brazil's democratic history.

${ }^{7}$ Singer adopts the definition of his father, Paul Singer, arguing that the sub-proletariat is a social category that sells its labor power below what is necessary for social reproduction under normal conditions. As survival strategies, this highly heterogeneous group relies on occasional wage work, informal exchange, opportunistic engagement with the economy, state transfers, charity and crime (Saad-Filho and Morais 2018, 196). These authors called them the informal working class, which is the preferable term. The authors also remark that, since the advent of neoliberalism, the dividing line between the informal and formal working class has become increasingly blurred. In parts of the text, I chose to use the 'working poor' because it alludes to both class and the conditions of social reproduction.
} 
through a Left debate and action, Lula transformed them into a political actor by shaping his discourse and political program to their conservatism.

Lula succeeded in achieving economic stability, which was particularly important to the informal, non-unionized workers. But unlike all previous governments, he was able to substantially improve the quality of life of the very poor, particularly by increasing their purchasing power. Such an accomplishment resulted from not only the cash transfer program, the Bolsa Familia, but also the $24.25 \%$ real increase in the minimum wage during his first presidential term (Singer 2009, 92), which strongly impacted the income of families who were relying exclusively on the pension of an elderly household member. Lula's social policies also included the provision of popular credits, support to family farmers, housing, and electricity to remote areas, among others, which altogether enabled an increase in popular consumption, an expansion of the domestic market and the creation of more employment opportunities. His welfare policies were material evidence of his intention and ability to put in place a transformative agenda benefiting the poor (thus serving as a powerful basis for support).

Reaching the poor population through federal programs, Lula delivered a symbolic message: 'the state [or Lula] cares for the lot of every Brazilian, no matter how wretched or downtrodden, as citizens with social rights in their country' (Anderson 2011). As Anderson stresses, the image of a caretaker of the poor became Lula's 'most unshakeable political asset' (Anderson 2011). Bolsa Família, despite being managed impersonally - and thus contrasting with the kind of clientelism characteristic of classic populism (Anderson 2011) - had 'immediate and palpable effects on the president's political fortunes' (Hunter and Power 2007, 25). Other social programs, Oliveira $(2006,19)$ argues, were so poorly managed that they achieved virtually nothing besides reaffirming Lula's strong leadership and caring image.

Singer argues that Lula established an ideological bridge with the conservative sub-proletariat by succeeding in assisting them only by pursuing a weak reformist agenda. ${ }^{8}$ Without denying the significance of improved material conditions for vulnerable people under Lula's rule, it is necessary to highlight the emergence of an equally important development: the fetishization of Lula as a representative of the poor. Lula came to embody popular hopes and under his leadership created a sense among the working poor that they had become the main social force in power.

Lula had the same social background as his supporters and incorporated the poor's culture and language. In the past, this was not an asset for him but it became so after his first successful term in office. His personal history as a humble, northeastern, working-class migrant began to affect people's self-esteem, already suggesting an emerging fetish around 'President Lula' (as he is still called today). Such a dynamic increased his credibility as 'the champion of the poor', while expanding his government's legitimacy.

Anderson (2011) remarks that Lula's direct relationship with the masses prevented the media from shaping the political undercurrent in the country, as it had been able to do in the past, when framing Collor as 'the 'Maharajas' hunter' during the 1989 presidential campaign, or Cardoso as the 'inflation tamer' during the 1994 and 1998 campaigns. The 2006

\footnotetext{
${ }^{8}$ Singer's thesis is sophisticated and nuanced. In this article, it is not presented or endorsed in its entirety. 'Lulism' has provoked considerable academic repercussions in Brazil, which this article also reflects on only partially. What I focus on here is the electoral realignment phenomenon and the inception of Lula's leadership over the masses, both of which Singer pointed out and offered convincing historical and contextual explanations for.
} 
election revealed an effective loss of the political power of the media while the masses assumed a protagonist role by effecting political power through voting based on their connection to Lula, not only giving him a second mandate, but also allowing the PT to remain in power for two subsequent elections.

\section{Lulism and populism}

According to de la Torre, '[l]eft-wing populists emerged [in Latin America] as a result of widespread popular resistance to neoliberalism' (2016, 63-64). While it holds that the PT came to power as a result of discontent over the effects of neoliberal reforms, Lula's leadership of the marginal masses emerged despite, if not because of, his compliance with the (neoliberal) order. Furthermore, it is precisely the working class disorganization and depoliticization, both deepened by neoliberalism, that together form one of the pillars of Lulism. In Filgueiras' words $(2013,388)$, Lulism did not originate only as a result of Lula's poverty alleviation policies; more importantly, it reflected the identification of Lula as a representative of those fragmented and disorganized social segments that could not express themselves autonomously and independently in the political arena. Paradoxically, the rise of Lula (and the PT) to power manifested the disempowerment and disorganization of Lula's own class (Oliveira 2006, 11). Even though Lula maintained an organized and critical electoral base - the MST, for example, was part of it - it was insignificant in size.

Contrary to Laclau's idea that 'there is no populism without discursive construction of an enemy' (Laclau 2005, 39), Lula united the electorate using a social conciliation discourse. This does not invalidate the hypothesis of populism, but rather points to the limits of empiricism found in the literature. If Singer is right, social conciliation allowed for the expression of an ideological unity with the working poor, just as an antagonistic discourse could in a different context. Furthermore, in a deeply divided and unjust society such as that of Brazil, social conciliation is no less fetishized than many forms of 'us-and-them' divides.

Lula realized, however, that social conciliation served to aggregate the masses but not to win the elites' trust. Oliveira $(2006,6)$ stresses that in Lula's first interview after his second electoral victory, he 'complained bitterly of not being the choice of the rich, pointing out that bankers have never earned so much money as under his government'. Lula was right, but chose to frame his election as 'a victory of the poor'. The media subsequently fueled the polarization of the rich and the poor. Of course, the dichotomy was figurative. First, Oliveira (2007) notes that the other half of the electorate was not composed of only the rich. Second, as Lula's statement informs, his administration was not (and not even primarily) supporting only the poor; thus, his election was also a victory of the rich. This, however, remained invisible.

The polarization of rich and poor bears relations with class conflict, but cannot be equated to class struggle (Singer 2013). According to Singer, 'the success of Lulism involved a social solution from above, creating both a depolarization [of capital and labor] and a repolarization [of rich and poor] politics' (Singer 2012, 157 as quoted in Filgueiras 2013, 388, author's translation).

Although Singer would agree that Lulism incorporates several elements of populism, for him, the PT political project was a genuine and complete project of the sub-proletariat 
with a conservative ethos, that is, an authentic representation of the working poor, able to respond to their needs. In Singer's view, there is no fetish. For him, Lulism could be considered as the politics of the sub-proletariat, even if they only attempted to reconcile with those of the bourgeoisie. In Singer's thesis, Lulism was a successful model in arbitrating the interests of the two essential classes: the bourgeoisie and the proletariat (see Boito 2013).

This, however, is problematic. First, Singer seems to disregard the asymmetries in the power relations between the two essential classes, as noted by Boito (2013). Second, to infer that the PT executed the political project of the sub-proletariat, it is necessary to look at the state's overall politics. This helps to identify where and how the policies aimed at the poor's interests were articulated - and made sense - economically and politically, as part of a broader social context. This is what the next sections examine.

\section{Disclosing the economic basis of the PT's political project}

The combating of poverty and social inequality without social confrontation - the basis of Lula's ideological and social project - meant, in practice, having an economic project with two legs: one developmentalist, the other neoliberal. The latter was a continuation of Cardoso's prescription, whereas the former represented the novelty of the PT's strategy. Organic intellectuals of the party (see Pochmann or Sader in Sader 2013) have called the political project 'neo-developmentalist', defending the advancement of a post-neoliberal pattern of development in the country despite the maintenance of the neoliberal macroeconomic orthodoxy. In Sampaio Jr.'s critical view, the PT's neo-developmentalist project intended to

reconcile the 'positive' aspects of neoliberalism - unconditional commitment to currency stability, fiscal austerity, the search for international competitiveness, the absence of any kind of discrimination against international capital - with the 'positive' aspects of the old developmentalism - commitment to economic growth, industrialization, the regulatory role of the state and social sensitivity. (2012, 679, author's translation)

However, if the combat of social inequality within the established order were two political agendas that did not seem to combine (Singer 2009, 96), developmentalism and neoliberalism were two policy prescriptions that, together, seemed unsustainable, either from the mainstream perspective or from the neo-developmentalist heterodoxy (Morais and SaadFilho 2011, 523). On the one hand, neoliberal macroeconomic policies impose real limits on growth, industrial competitiveness, public investment, social welfare and state activism, all of which are promoted and expected under developmental policies. On the other hand, the expansion of domestic consumption, imports and public spending, which developmentalism promotes, deteriorate the current account balance, primary fiscal surplus and inflation control, thereby undermining the macroeconomic stability brought about by orthodox policies.

Within the political sphere, developmentalist and neoliberal economic policies were accompanied by a tension between a productivist and a rentier social coalition. The productivist coalition agenda included the control of foreign capital flows, interest rate reduction, domestic currency devaluation, protection of the industry against the 'Dutch disease' and deindustrialization, an increase in public investments in infrastructure and a reduction in inequality (Filgueiras 2013). The rentier coalition, in turn, advocated high 
interest rates, the free flow of foreign capital, a floating exchange rate, central bank independence and the rejection of state-led income redistribution.

Despite this tense economic and political arrangement, Brazil started to experience an economic upswing, followed by social improvements that were visible during Lula's first term in office. In December 2010, Lula ended his presidential term with an unprecedented popularity level of around $90 \%$. How was he able to reconcile the irreconcilable?

Agricultural exports have a prominent and revealing political role in answering this question. The next section shows that there was no leadership miracle.

\section{Agribusiness and the commodity boom: a political windfall}

Agricultural export was critical in lifting the economy out of the stagnation and crisis it faced in the early 2000s. At the end of Lula's first year as president, the agribusiness trade surplus had offset the country's current account deficit, ending the period of macroeconomic instability and producing the first growth cycle, both having a substantial political effect for Lula and the PT. Lula thus reaped the political fruits of a convergence of domestic and international factors.

The productivity increase in the agricultural export sector, which reflected the technological advancement stimulated during Cardoso's last administration, resulted in sizable soya harvests that were traded on the international market not only at exceptional prices, but also under the condition of strong domestic currency devaluation, thereby generating extra revenue. Brazil was in crisis when Lula first came to power, but was ready to feed into and benefit from the global commodity super-cycle driven by emerging markets, particularly China.

Over the course of one year, from 2003 to 2004, the annual GDP growth rate increased from $1.1 \%$ to $5.8 \%$, and by the end of 2005 , Brazil was experiencing a growth cycle driven mainly by (agricultural) exports (Carvalho 2018). According to Loureiro $(2019,5)$, between 2003 and 2005, exports corresponded to $42.7 \%$ of the rise in aggregate demand against $39.5 \%$ and $4.5 \%$ of private consumption and investment, respectively.

This externally-driven growth cycle during Lula's first administration unleashed a series of processes that led to a second and virtuous growth cycle with very different characteristics (Loureiro 2019). Together with macroeconomic stabilization and lower inflation, the first growth wave helped to recover the average real salary after mid-2004 (Filgueiras 2013, 398), stimulating an increase in domestic consumption. The extraordinary trade balance surpluses mentioned above stimulated the return of foreign investors to the economy. With investments, production, trade and consumption on the rise, the fiscal budget increased, allowing for the expansion of income redistribution programs and public investments, both of which have an impact on employment opportunities. The improvement in employment and income - through income transfer programs, a minimum wage increase and access to popular credit - further stimulated an increase in consumption. From 2006 to 2012, economic growth was domestically driven, mainly by domestic consumption and investment (Loureiro 2019). Yet this second pattern of growth was not detached from, but rather reinforced by, and partly reliant on, the commodity export sectors.

Several authors claim that the second growth cycle resulted from a state-led policy inflection (Barbosa and Souza 2010) or policy hybridization (Morais and Saad-Filho 2011) characterized by state activism in relaxing macroeconomic policies and pushing 
forward developmental policies. Politically, the inflection meant alleviating the tensions between the productive and rentier bourgeoisies while benefiting the poor. The extraordinary performance of agricultural exports - this time together with the extractive industry (oil, mining and gas) - partly explains the temporary lift of the policy incompatibility within the PT's political formula. Such a role became evident and possible during Lula's mandates, when commodity prices and international liquidity were exceptional - two contingent and exogenous factors to the national economy.

Carvalho (2018) mentions that the rise in international commodity prices not only increased incentives and resources for investments in the commodity-producing sectors, but also engendered a chain effect for the related sectors, raising government revenues needed for the expansion of public investments. The massive inflow of foreign investment during this period responded to the opportunities in the agricultural sector, the extractive industry and related infrastructure (Gonçalves 2012,13) - besides the opportunities arising from Brazil's large domestic market.

Many of the investments of the Growth Acceleration Program (PAC), a state investment platform launched in 2006, were also induced by the commodity production sectors. The PAC became a dynamic center of growth in subsequent years (Sitcovsky 2013, 120). Other state initiatives, such as the provision of subsidized loans from the National Development Bank (BNDES) to national corporations, or South-South investments and partnerships, targeted and boosted the primary sector.

The evolution of employment in this period occurred at the base of the Brazilian social pyramid, corresponding to the labor-intensive, low-paid and low-skilled sectors that were driving economic growth, in particular, the service sector, construction and extractive industries (Pochmann 2012). It is important to note that the salary gains, particularly in the service sector, were transferred to the final service costs, resulting in service price inflation (Carvalho 2018). It was only possible to increase income (and consumption) at the base of the pyramid and to retain overall control of inflation because primary commodity exports and foreign investment (both generating a massive inflow of foreign currency) induced exchange rate appreciation (Carvalho 2018). This cheapened imports and prevented price readjustments in the sectors that, unlike services, faced international competition, thereby enabling inflation targets to be met.

Allowing the exchange rate to fluctuate according to market forces was a political choice that had several effects on the patterns of production and trade. While the steady appreciation of domestic currency favored the assemblers of imported industrial inputs, it undermined the internal and external competitiveness of several branches of the national industry. This implied that the increase in domestic consumption (as a driver of growth) was linked to the development of a growing industrial trade deficit. In the mid-2000s, this perverse dynamic could continue, since the trade surpluses of the primary commodity sector compensated for the industrial trade deficit. The primary sector, which exploits cheap and abundant production factors, was highly competitive, regardless of the exchange rate overvaluation.

Maintaining high interest rates was also a political choice that produced unequal and conflicting effects between the productive and rentier bourgeoisie, as well as society at large. It increased the cost of bank credit operations and undermined the domestic capacity of private investments. While some businesses perished, corporate financialized industries (several in agribusiness itself) could expand, relying on external financing, either 
through intercompany loans, buying and selling equity stakes, or borrowing abroad at favorable rates. The state itself could increasingly rely on external financing, selling public debt bonds with very attractive interest rates leveraged by the Central Bank benchmark rate. In a moment of expansion of the global economy, Brazil became a hub of foreign investment and financial transactions.

That meant that, besides offsetting the industrial trade deficit, primary exports were also remunerating the stocks of foreign capital, both perversely enhanced as a consequence of the growth model (Andrade 2016). Primary exports prevented an immediate erosion of the balance of payments (BoP), public accounts and inflation control (Filgueiras 2013, 37; Carvalho 2018). Therefore, these exports helped to sustain the economic policy inflection that promoted growth leveraged by investment and domestic consumption while maintaining high interest rates, currency overvaluation and a contractionary fiscal policy.

In this particular international context, primary commodity production and exports helped the state promote a concrete, albeit temporary and limited reversal between the neoliberal and neo-developmentalist policy effects on the economy and society, letting the latter stand out - the material basis of Lulism. However, they did not help transform the power asymmetries between the two essential classes in state decision-making, nor did they transform the inequalities in economic and social relations, which form the abstract basis supporting the argument for populism and the fetish of the neo-developmentalist project. The performance of the primary commodity sectors reinforced, deepened, sustained and concealed its structural vulnerabilities and dependencies, which are discussed in the next section.

\section{The development pattern and social relations: deceiving the class mandate received at the polls}

The pattern of economic growth and development contributed to the deterioration of the commodities - manufacture composition of the country's trade balance (Morais and SaadFilho 2011, 523) and enhanced a regressive primary specialization trend in the international division of labor. As the productive structure became less diversified and integrated, reflecting the dismantling of industrial chains since the 1990s, the country entered a fragile path of international market dependence and reliance on exchange rate overvaluation. Depreciating the real would make imported products (on which the country came to depend) more expensive, advancing instead of relieving the negative effects on the trade balance, consumer prices and inflation - all of which came to be experienced soon after the end of the commodity boom.

The macroeconomic policies mentioned above stimulated a massive, state-operated transfer of public income - leveraged by the effects of growth on the fiscal budget - to the private sphere of national and international owners of financial assets (Carvalho 2018). In this way, the state limited its capacity to invest and redistribute. The increase of domestic assets owned by foreigners (e.g. state- and private-owned enterprises and services, bonds of public debt, private equity stakes) created a corresponding intensification of income and profit repatriation, or a draining of income and capital. The exchange rate overvaluation further stimulated remittances and foreign speculative investment (Andrade 2016,11 ) by increasing their real return when converted back to hard currency. 
The patterns and intensity of financial transactions between residents and nonresidents of the country placed a structural burden on the current account of the BoP.

The policy inflection at the basis of the neo-developmentalist project was fragile, depending on and nurturing itself through the primary sector and foreign investment, both contingent to the international context. It was also weak: the economic model was structurally inadequate for attaching domestic demand dynamism to a corresponding industrial, technological dynamism, as well as for linking the fiscal gains to a corresponding expansion in public investment and social redistribution. It promoted a limited convergence of class interests within the bourgeoisie, as well as within the working class, shaped by the constraints of monetary policies and financial dominance.

Instead of neo-developmentalism, the PT promoted a 'reverse developmentalism' (Gonçalves 2012). The structural axis of the (old) national developmentalism had been inverted, inducing a reprimarization of exports, de-industrialization and the import of industrial goods (literally the reversal of import substitution), greater technological dependence and denationalization, a loss of international competitiveness and greater external structural vulnerability - making the Brazilian economy prone to crises (Gonçalves 2012).

Different from the first years of the 2000s, agribusiness exports were no longer a contingent element that helped lift the country out of crisis and launch a neo-developmentalist experience. Agribusiness for exports became endogenous to the state-sponsored pattern of accumulation and integral to the regressive structures of production, trade, consumption and finance. Vergara-Camus and Kay (2017) pointed to the inability of leftleaning governments in Latin America to confront agribusiness power and deal with the state's rentier character. In the case of Brazil, it was not a matter of the government's inability, but rather its direct economic and political reliance on agribusiness and the extractive industry for sustaining its political project.

To avoid these flaws, the entire macroeconomic policy framework would have to change, with a corresponding demise of the rentier coalition's ascendance in policymaking. As Filgueiras and Gonçalves sharply note,

[... ] the interest rate in Brazil is not only the classical instrument of monetary policy; it is much more than that. [ ...] it constitutes the fundamental element that structures and at the same time expresses class and power relations. (2007, 180, author's translation)

The patterns of employment creation, earned income distribution and consumption promoted in this period benefited the very poor, albeit at the margins. These patterns also created a (dangerous) double squeeze on the urban middle class and part of the formal proletariat, which was still significantly poor. The latter were users of public services (e.g. health, transport, education), which worsened in terms of quality, cost and service capacity, whereas the former were users of urban services (e.g. restaurants, hairdressers, domestic services, construction) affected by the price inflation resulting from the increase in labor costs. The middle class also experienced a decline in the availability of formal (and better remunerated) employment opportunities. In brief, the neo-developmentalist project increased tensions within the broad working class (while easing those within the bourgeoisie) (Filgueiras and Gonçalves 2007).

Finally, it is important to remember that the income redistribution did not reach the top of the pyramid. It is worth looking at the fostered pattern of asset ownership. Land and natural resource assets, which have a historically narrow basis, became even more 
concentrated after the 2000s. Comparing land distribution patterns, Teixeira (2011) shows that, between 2003 and 2010, large properties increased by $16 \%$ in number and $48.4 \%$ in size: an additional 104 million hectares of private property, $70 \%$ of which is found in the Amazon region. In 2003, large properties corresponded to $51.6 \%$ of the country's total rural property area, compared with $56.1 \%$ in 2010 ; all other property size groupings reduced their share of the total property area.

Concentration also marks the pattern of financial asset ownership. Consequently, several authors have questioned the assertion over decreasing inequality and poverty rates in Brazil (Oliveira 2009; Sitcovsky 2013, 134):

[... ] the mere payment of the domestic debt service, around 200 billion reais per year, against the extremely modest 10 to 15 billion of Bolsa Família, does not require much theoretical speculation to conclude that inequality is increasing. (Oliveira 2009, author's translation)

Amann and Baer $(2012,420)$ have asked 'whether further substantial improvements in the distribution of income can be realized in the context of a highly skewed pattern of asset ownership'. Indeed, this brings into question the forms and effectiveness of income redistribution, including cash transfer programs and other social policies, all of which were definitive to the success of the PT in presidential elections. The next section briefly exemplifies how these tensions touched upon the countryside.

\section{The rural staging political tensions and appeasements}

In December 2010, the Institute of Agrarian Reform (INCRA) presented statistics showing that, during Lula's terms in office, the Agrarian Reform Program reached its best ever performance in regard to designated area and number of settled families. The well-known scholar Ariovaldo U. de Oliveira contested the statistics, explaining that INCRA aggregated land titling and land regularization with the expropriation and implementation of new settlements. According to his calculations, only $34.4 \%$ of the total number of land settlements documented by INCRA between 2003 and 2009 were truly new settlements (Arruda 2011). And in 2011, under Rousseff's administration, the number of settled families reached the lowest point in 16 years (Pericás 2017, 61).

By contrast, the volume of public resources Lula and Rousseff spent on the 'family farm' agricultural sector was without precedent - although significantly lower than the volume spent in large-scale, highly capitalized agriculture - and had an impact on rural income and productivity. The rural credit program (Pronaf) mostly benefited the better-off (small-scale) producers, while programs such as the food procurement program (PAA) or targeted credit for women and youth benefited poorer producers (Sabourin 2007), including most of the beneficiaries of agrarian reform. The number of rural poor decreased by $38.7 \%$ between 2003 and 2009 (author's calculation based on DIEESE 2011, 143).

For the MST leadership, agrarian reform itself became a sort of social compensation policy during the mandates of the PT. Mafort $(2018,19)$, who is part of that leadership, argues that the consolidation of family agriculture occurred at the expense of structural and transformative agrarian reform, class consciousness formation and movement-building. Agrarian reform, which once formed the core of the PT's political project, assumed a different nature during the party's mandate, as did the social struggle for land. 
Pericás (2017) presents other interesting figures covering the period in which the economic crisis commenced. In 2012, 70\% of the budget allocated to INCRA was cut. During the same period, $42.9 \%$ of land reform settlers had abandoned their land, and 35\% had illegally transferred their property (Pericás 2017, 60-61). At the start of 2013, 36\% of the families in land reform settlement schemes depended on the Bolsa Familia (Pericás 2017, 59-60). Unsurprisingly, authors such as Filgueiras and Gonçalves (2007) argued that several of Lula's social policies were unable to disarm the structural mechanisms of poverty reproduction. Maintaining the poor in a permanent state of insecurity and dependence, they only functioned as a buffer of social tensions within a liberal project or instruments of political manipulation (Pericás 2017). In the countryside, many programs simply mitigated a state-sponsored erosion of rural social reproduction.

The MST remained critical of the government and politically active during the entire period, but could not escape the effects of populism on its base, which, on the one hand, was at the forefront of the conflict related to agribusiness expansion, and, on the other, was benefiting from several social and income policies. Both dynamics were linked and promoted by the government. The movement was put into a deadlock: structural agrarian reform, its main demand, did not make sense in the PT development model and advanced very little; as a result, the movement lost the power of mobilization. The MST remained politically engaged, but became less effective. To a certain extent, placing more emphasis on the economic-corporate demands of its landed base, which were partly met by public programs, the movement became dependent on Lulism (Almeida 2012) - even if there was a sharp understanding and critique of the development model, its logic and corresponding powers among its ranks.

The irony of Lula's political project in rural areas was having the state capacity to redistribute income, expand credit and other forms of support to the rural working poor tied to the encroachment of capital (and thus, to its legitimacy) on land and natural resources. This signifies that, beyond concessions to the rural poor, social welfare was part and parcel of a vicious social alliance between the poor and the dominant capital - an alliance that deepened structural class contradictions.

Tackling poverty and social inequality were rendered exogenous to capital-labor relations and to the dynamics of income and wealth accumulation that bring them into being. Social programs, such as Bolsa Familia, could be presented as administrative solutions (with a temporary, immediatist, selective and assistentialist nature), depoliticizing both poverty and inequality (Oliveira 2006, 22). As Sitcovsky observed,

[t]he intellectuals of the Workers' Party, by presenting the thesis of post-neoliberalism, neodevelopmentalism, and arguing for a virtuous growth cycle, [...] created a mystifying [perhaps, fetishized] vision of reality, covering up reprimarization, deindustrialization and the deepening of financialization. Likewise, by declaring the end of extreme poverty through Bolsa Família, and reducing the social phenomenon of poverty to an income issue, they eventually reified it. (2013, 135, author's translation)

The next section resumes the discussion on populism and elaborates on Lula's model.

\section{A new modality of left-wing populism: drawing from above and below}

I am no longer a human being; I am an idea - an idea fused with yours (Lula's statement on the day of his arrest, 7 April 2018) 
Lula's model of populism is not easy to grasp - it is nuanced. Simple labels fall short in describing, much less analyzing it. Lula and the PT are associated with the left, whose politics is inspired by a critique of capitalism and a corresponding alternative vision. Concerns with poverty, employment, income and working class mobilization have been constitutive of leftist politics. Yet 'populism of the left' does not adequately describe the PT experience in power.

The populism of the left is historically associated with the fetishization of patterns of accumulation from below in which the rural economy assumes central importance. This type of populism is marked by the pursuit of economic and social policies that assume inherent properties of small-scale property and production, family labor, local culture, rural development and nationalism as the bases for social justice, equity, autonomy (rural or national), sovereignty and emancipation. The fetish lies in the fact that none of these - the scale, the family, the locality, the territory or the nation - relate to the causes of capitalist exploitation, poverty or inequality (see Byres 1979; Kitching 1989; and Brass 2000). Consequently, populism from below, even if having a sophisticated political agenda, fails to describe in theory, and to resolve in practice, how forms of (petit commodity, national) production and accumulation are integrated into broader capitalist and international commodity relations. Their politics fail 'the people', in part or in total, leaving unrestrained forms of capitalist exploitation, which in theory they oppose (Kitching 1989, 181-3).

Yet it is likely that populism from below is economically more democratic, mobilizes the grassroots, has a leader that comes from below and calls upon or urges the people to act, rallies supporters, bends the economic elite and so on. However, these and other features should not be inferred theoretically, but rather described empirically. In contemporary Latin America, perhaps Morales in Bolivia could be better described as a leader embodying populism from below. Other examples can be found in the African context, such as Tanzania under Nyerere's rule, where the widespread access to and dependence on land for social reproduction made accumulation from below conceivable as a political project.

Lula's personal history and the social characteristics of the population he mobilized created a sense of a government 'for and from below'. Lula promoted personal ties with the poor, but also catered to their real interests, enabling income redistribution that is a progressive and popular demand. This has been crucial to the way in which Lula and the PT secured and exerted power. However, Lula did not try to implement a model of accumulation from below. His populism therefore belongs to a new modality of populism of the left.

Lula did not attempt to dispute control over the (re)organization of property, production, appropriation and accumulation within society. In his government, the dominant classes (e.g. banks, financiers, multinational corporations, national and international holders of public debt bonds) benefited from structural macroeconomic policies, while the working class benefited from income redistribution measures with essential limits in scope, scale and sustainability, conditioned by the former. The benefits for the working class were short term, selective, restricted and assistentialist. The PT governed for large capital - for the already privileged and powerful. The very expansion of primary exports in this period can be considered a manifestation of a neoliberal, financialized pattern of accumulation from above. 
Accumulation from above can be defined as the formation or expansion of (preexisting) dominant capital (or groups of capital) through processes of social income and wealth appropriation (as in the privatization, expropriation, and direct appropriation of public land and resources, in addition to the control of production, trade and finance), for which state command is essential. Neoliberalism is a specific pattern of accumulation from above, assuming a specific form in the Brazilian context. The fetishization of such a type of economics can assume various forms and enable the emergence of populist politics supported and legitimized by the masses.

Populism from above tends to be economically and politically transformative, changing the relations of power within the bourgeoisie and, consequently, the patterns of production, distribution and accumulation. These transformations require economic, social, political and institutional reforms, possibly requiring top-down decision-making, a disciplinary, coercive state, and strong leaders that preach to the masses. President Vargas (1930-1945 and 1950-1954), who led the process of industrialization in Brazil, could be considered an example. Lula did not have these characteristics, and his policies were not as transformative; rather, he maintained and nurtured the material and political basis of neoliberalism through corresponding macroeconomic and social policies, but under the promise of transforming the living conditions of the working poor.

In conversation with Gramsci and Singer, Oliveira (2006) argues that Lulism flipped Gramsci's formula on its head: instead of the moral ascendancy of the possessing over the laboring classes, the dominant was bent, consenting to be led by a representative of the dominated, yet simply to reinforce the structures of their exploitation - a 'hegemony in reverse' (Oliveira 2006). Lula, in turn, conceded to capital as a condition of power.

The myth of his political project relates to the illusion of creating an endogenous growth process yielding social equity (neo-developmentalism) without attempting to renegotiate power and property, rallying popular power in society and state decisionmaking - a hallmark of populism. The masses were political agents in the instance of elections, expressing preferences, asking, hoping and waiting for support and change; however their political participation was instrumental.

In some respects, petismo-lulismo represents a far purer populism - the impossibility of a politics based on organized class - than the classic cases of Vargas, Perón and Cárdenas. These were, in various ways, authoritarian forms for the inclusion of the working class in politics [under the tutelage of the bourgeois state]. Today's neo-populism represents not the authoritarian inclusion but the democratic exclusion of those classes from politics. (Oliveira 2006, 19)

Delivering material improvements to the poor without active engagement, Lulism reinforced a passive political actor, allowed or stimulated political lethargy and constrained more ambitious demands of its own organized social base (as with the case of agrarian reform and the MST), even creating important arms of social co-optation (as with the case of CUT).

In brief, Lulism was the unification of the main working class fraction without class politics, class forms of consciousness, organization or political struggle. Lulism was embodied by the election of an authentic working-class president devoid of working-class power, even though part of the left in Brazil pretended that this was the case (Oliveira, TV interview, 'Roda Viva' Program, July 2012). This is exactly the uncritical treatment - or fetishization - of transformative politics, so emblematic of populism of the left. Lula did not reflect 
the ideology of the ruling class, but came to represent the notion that it was possible to succeed within the order.

The temporary success of his economic model was organically linked to a process that undermined long-term economic development and social cohesion, leaving two easy scapegoats - the left and the poor - increasingly exposed. Lula's populism was economically weak and politically vulnerable, allying a partial realization of the interest 'from below' to the reproduction and expansion of a pattern of accumulation 'from above'.

In 2011, with the global economy still in crisis, foreign investment stagnant and the commodity price boom at its end, the BoP, financial, fiscal, monetary and real crises started to swell, becoming critical after 2013. As they unfolded, they exposed the limits of the PT's political project and their deceptive representation of the working poor. The spell crumbled in Rousseff's hands. The next section sheds light into the political crisis and the recent authoritarian turn.

\title{
The 2013 crisis and the political turn
}

\author{
Eu não vou pagar o pato (Fiesp) \\ ... e a multidão caiu feito um patinho.
}

Rousseff's administration reacted to the economic crisis by advancing the developmentalist agenda. She intended to stimulate investment by granting a tax-friendly agreement to targeted industries, making the exchange rate more competitive and reducing the interest rate to its lowest in years. This move, however, irritated the rentier coalition, who saw it as a threat to their economic privilege and political dominance. Rousseff also failed to facilitate the expected economic recovery, having underestimated the extent of the global crisis and taken a series of precipitated and clumsy measures. In 2014, she was reelected by a small margin of votes and, at the dawn of her second term, receded her developmentalist promises and redirected her policies to the priorities of the financial market - this time, irritating her supporters and being left politically on her own.

It is worth recalling that, in June 2013, the PT was taken by surprise when more than one million people angrily took to the streets to express widespread dissatisfaction with the lack of provision of public services across the country (Saad-Filho 2014). The initial protest against the rise of bus tariffs in São Paulo was catalyzed after ruthless political repression. Thereafter, demonstrations multiplied in size and diversified in terms of social composition and political demands throughout the month (Saad-Filho 2014, 1). Although originally ignited by leftist claims to services such as free transport, the protests were soon subsumed by the 'entry of a disparate mass of middle-class demonstrators supported by the mainstream media' (Saad-Filho 2014). The left withdrew from the streets, and subsequently, the 2013 events fermented into an anti-PT sentiment, ultimately boiling over with Rousseff's 2016 impeachment.

Operation Car Wash (Operação Lava Jato), an investigation of corruption and money laundering conducted by the Federal Police starting in April 2014, was an important catalyst. As it unfolded, the operation started to torment politicians, prominent entrepreneurs and former employees of state-owned companies (such as Petrobras). Under the radar of the investigation, they were threatened with the possibility of losing their political mandates and facing jail sentences, which mobilized them to seek the containment of the 
operation at all costs, including pushing for Rousseff's impeachment. In the public sphere, Lava Jato was not only demoralizing politicians, but also undermining the overall legitimacy of the state, the national congress and other political institutions. With the explicit use and support of the corporate media, this operation started to instrumentalize corruption and moralism to gain mass traction in favor of impeachment while keeping the interests of powerful financialized economic groups invisible and intact. ${ }^{9}$

The vote from the agribusiness caucus in congress was decisive for impeachment. The industrial and agrarian bourgeoisie abandoned the PT, voting against the developmentalist state - or against their interests - to form a single bourgeois coalition with the rentier class. Carvalho (2018) provides two possible explanations. First, taking state control from the PT, politicians could hold back Lava Jato, which could compromise the entire political system. Second, by supporting impeachment and securing tighter control of the state, economic sectors could save themselves from 'the cost of one of the greatest economic crises in recent history, imposing it on the rest of society' (Carvalho 2018, chapter 3, A panaceia do impeachment, author's translation). São Paulo's Industrial Federation (Fiesp), the main beneficiary of Rousseff's recovery plan, launched the pro-impeachment slogan, 'I will not pay the price' (Eu não vou pagar o pato), which was adopted by the people, unaware of the cynicism.

The vote of the agribusiness caucus, in particular, seems to reinforce one of the arguments put forward here: that the economic and political importance of the sector emerged and made sense in the context of neoliberalism and financialization. ${ }^{10}$ Boito and SaadFilho $(2016,194-5)$ also remark that the accumulation strategies of the domestic bourgeoisie (or the productive coalition) depended on imperialism and the international (rentier) bourgeoisie, sharing an ideology, culture, finance and other interests.

Singer (2015) suggests that the bourgeois political alignment that led to impeachment was motivated by the fear of growing state activism, particularly seen during Rousseff's first term, and of the PT's symbolic, moral and historical alliance with the working class. The bourgeoisie's relationship with Lula and the PT always carried the fear of radicalization. In a country with enormous social inequality such as Brazil, the ruling classes experienced Lulism as a first manifestation of the class struggle - even though it temporarily placated social tensions. Therefore, by giving up their immediate interests, the productive coalition could avoid the greater risk of a worker takeover of politics (Singer 2015).

Lulism possessed an organic transformative potential not usually found in other instances of populism. Considering the social profile of its supporters, Lulism had the potential to express demands deriving from, and thus compatible with, the material and political interests of the working class. It could also develop the latent possibility of mass mobilization and active intervention into the control of economic affairs. The development of such potential, however, was conditioned upon populism's very demise.

The PT's 13-year period of governance prompted certain transformations in that direction, for example, inciting an extensive and extended notion of citizenship and rights that could have unfolded into a new moral ethos to redefine social relations in the country.

\footnotetext{
${ }^{9}$ The rigged political role of Lava Jato, recently revealed (see the leaked material published by The Intercept-Brazil), reached a pinnacle with Lula's imprisonment, mentioned ahead.

${ }^{10}$ In 2005, the vote of the agribusiness caucus saved Lula from an impeachment process after the 'mensalão scandal'. In this context, commodity prices were high, and the sector was economically and politically more comfortable to support (and continuing to count on) Lula's government.
} 
What could happen when the new mass of people with a formal education did not find employment opportunities compatible with their new material and cultural aspirations (Singer 2013)? The initial wave of protests in 2013 reflected the growing realization that good jobs were scarce, the quality of urban services had deteriorated, and the cost of such services had nevertheless increased. The situation evolved, however, in the least desired way up to the 2018 presidential election.

Safatle's (2018) remark is poignant: what was dramatic about the latest election was that those who rightly wanted a rupture with the establishment were captured by and radicalized to the extreme right, not the left. How did this occur? While this is not an easy question to answer, it is fundamental to Brazil's future. This new modality of populism of the left that aligns its progressive agenda to financial capital accumulation provides some insights into the recent shift to authoritarian, morally conservative and ultraliberal economic politics.

The economic crisis the PT led the country into was a crisis of the neoliberal pattern of capital accumulation, externally dependent. Having done nothing to confront the power of the propertied and rentier bourgeoisie, or to organize and politicize its social base having in fact concealed the antagonism in its class alliances and political representation - the party was left with no legitimate authority, no basis of defense, and no line of attack when the economic crisis and political accusations rebounded.

Lula and the PT, and, unfortunately, the left in general, were at the mercy of conservative forces and the media, who were left alone to frame the explanations for the crisis. A fictional 'radical left' (of 'Marxists' and 'communists') was forced to shoulder the burden of the economic, social and moral collapse of the country. The PT and the left were scorned and branded as irresponsible, incompetent, negligent and, above all, deeply corrupt.

The PT resorted to the only remaining option: reinforcing Lula's leadership. Avoiding explanations and self-critique, the party seemed to sustain the idea that the social successes of the 2000s were directly and solely attributable to Lula and that he alone could bring them back. Arguably, the party allowed for the political butchering of Rousseff 'this inept woman' - in 2016, gambling that it could make its comeback under Lula in the 2018 election. It is important to note that Lulism is still alive and well; Lula was the favorite candidate in the presidential campaign and was likely to have been elected in 2018 if the Superior Electoral Court had not blocked his candidacy a month before the election was to take place. ${ }^{11}$

Lula's social base, having passively experienced a multitude of changes, particularly in purchasing power, but having not had a chance to understand why these changes were limited and short-lived, remained faithful. Almost as a corollary, that same social base was incapable of forming a political understanding to organize and oppose Rousseff's impeachment, which only reinforces the aspects and effects of populism discussed in this article. During the presidential campaign, Lula sought to unite the organized left but around him - ultimately achieving the opposite.

The Brazilian people, resentful of the low quality of public services and other effects of the neoliberal order, indiscriminately voted for the absolute dismantling of the state and

\footnotetext{
${ }^{11}$ After a controversial and expedited trial in the context of Operation Car Wash, Lula received a 12-year prison sentence for corruption and money laundering in April 2018. His campaign continued even in prison until September 2018, when Brazil's top electoral court ruled that his candidacy should be barred. The PT's substitute candidate, Fernando Haddad, began his campaign a month before the election, adopting a strategy to make him a virtual image of Lula.
} 
supreme neoliberal hegemony - a tragedy for which Lula bears responsibility. Bolsonaro was elected as the option to remoralize public life, to bring economic and social order, and to 'put things right'. But whose order?

\section{Conclusion}

The contrast between 'the sheer electoral weight of the poor, juxtaposed against the sheer scale of economic inequality' (Anderson 2011) makes Brazilian democracy latently explosive. The country's republican history expresses it well: it is permeated by dictatorships, coups d'etat and populism, all making it evident that 'political democracy was never meant to reach the economic realm' (Ayers and Saad-Filho 2015, 600). The political system itself is a historically entrenched structure against working class formation and organized struggle. Lula's populism is part of this history, as is the impeachment of Rousseff, Lula's imprisonment and the election of Bolsonaro.

Populism can be politically and economically transformative, but it is socially conservative, reproducing rather than transcending social hierarchies and inequalities. The PT captivated the support 'from below' by promoting marginal income redistribution, innocuous for a transformation - much less an inversion - in power relations in society and the political system. Lula's populism symbolically bent, but economically served the powers 'from above'. His political choices not only cast down the goal of development with social equity, but also launched Brazil into a long-term trajectory of instability and crisis (Gonçalves 2012).

Since the impeachment process, the MST became more openly supportive of the PT. Its overt participation in Lula's 2018 presidential campaign shed doubt on whether it represented a questionable electoral pragmatism or a regrettable Lulism. On the day of his imprisonment, Lula powerfully declared that he had become 'an idea', set loose to spread among the masses. This 'idea' must be disputed. In the face of growing authoritarianism and attacks on workers, Lulism risks being reinforced, instead of gaining a critical understanding of the political nature and related limits of the Workers' Party project. Without this understanding, no reliable counter-alliances and strategies can emerge, let alone a conceivable path to emancipation. 'A luta continua', but class struggle (and class analysis) must resume its critical role.

\section{Acknowledgments}

I would like to express my appreciation to the ERPI team for creating this important platform for scholarship and movement-building. I am also grateful for the ERPI grant that contributed to this research. I would also like to thank my two anonymous peer reviewers for their constructive comments. Finally, I would like to extend a major thanks to professor Alfredo Saad-Filho for his encouragement and valuable insights in the early stages of writing this article.

\section{Disclosure statement}

No potential conflict of interest was reported by the author.

\section{Funding}

This work was supported by Emancipatory Rural Politics Initiative (ERPI): [ERPI Small Grant]. 


\section{ORCID}

Daniela Andrade (D) http://orcid.org/0000-0002-0766-5545

\section{References}

Almeida, Lúcio Flávio Rodrigues de. 2012. “Entre o nacional e o neonacional-desenvolvimentismo: poder político e classes sociais no Brasil contemporâneo." Serviço Social \& Sociedade 112: 689-710.

Amann, Edmund, and Werner Baer. 2012. "Brazil as an Emerging Economy: A New Economic Miracle?" Brazilian Journal of Political Economy 32 (3 (128)): 412-423.

Anderson, Perry. 2011. "Lula's Brazil." London Review of Books 33 (7): 3-12. Accessed 21 October 2017. https://www.Irb.co.uk/v33/n07/perry-anderson/lulas-brazil.

Andrade, Daniela. 2016. "Export or Die': the Rise of Brazil as an Agribusiness Powerhouse." Third World Thematics: A TWQ Journal 1 (5): 653-672. doi:10.1080/23802014.2016.1353889.

Andreucci, Diego. 2017. "Populism, Hegemony, and the Politics of Natural Resource Extraction in Evo Morales's Bolivia." Antipode 00 (0): 1-21.

Arditi, Benjamin. 2005. "Populism as an Internal Periphery of Democratic Politics." In Populism and the Mirror of Democracy, edited by Francisco Panizza, 72-98. London: Verso.

Arruda, Roldão. 2011. "Incra infla números de reforma agrária." O Estado de São Paulo, Política. https://politica.estadao.com.br/noticias/geral,incra-infla-numeros-de-reforma-agraria,685346.

Ayers, A. J., and A. Saad-Filho. 2015. "Democracy Against Neoliberalism: Paradoxes, Limitations, Transcendence." Critical Sociology 41 (4-5): 597-618. doi:10.1177/0896920513507789.

Barbosa, Nelson, and José Antonio Pereira de Souza. 2010. "A inflexão do governo Lula: política econômica, crescimento e distribuição de renda." In Brasil entre o passado e o futuro, edited by Sader Emir and Marco Aurélio Garcia, 57-110. São Paulo: Boitempo.

Boito Jr., Armando. 2013. "O lulismo é um tipo de bonapartismo? Uma crítica às teses de André Singer." Crítica Marxista 37: 171-181.

Boito Jr., Armando, and Alfredo Saad-Filho. 2016. "State, State Institutions, and Political Power in Brazil." Latin American Perspectives 43 (2): 190-206.

Brass, T. 2000. Peasants, populism and postmodernism: the return of the agrarian myth. Vol. 17. London: Library of Peasant Studies.

Byres, T. J. 1979. "Of neo-populist pipe-dreams: Daedalus in the Third World and the myth of urban bias." Journal of Peasant Studies 6 (2): 210-244.

Carvalho, Laura. 2018. Valsa brasileira: do boom ao caos econômico. E-book. São Paulo: Todavia.

Castilho, Alceu. 2017. Frente Parlamentar da Agropecuária compôs 50\% dos votos do impeachment e 51\% dos votos para manter Temer. Accessed 14 January 2018. https://deolhonosruralistas.com. br/2017/09/25/frente-parlamentar-da-agropecuaria-compos-50-dos-votos-do-impeachment-e51-dos-votos-para-manter-temer/.

CPT (Comissão Pastoral da Terra). 2017. Conflitos no campo, Brasil, 2017. Goiânia: CPT Nacional, Brasil. de la Torre, Carlos. 2016. "Left-wing Populism: Inclusion and Authoritarianism in Venezuela, Bolivia, and Ecuador." The Brown Journal of World Affairs XXIII (I): 61-76.

de la Torre, Carlos. 2017. "Populism in Latin America." In The Oxford Handbook of Populism, edited by Cristóbal Rovira Kaltwasser, Paul Taggart, Paulina Ochoa Espejo, and Pierre Ostiguy, 1-22. Oxford: Oxford University Press.

DIEESE. 2011. "Estatísticas do meio rural 2010-2011." Departamento Intersindical de Estatística e Estudos Socioeconômicos; Núcleo de Estudos Agrários e Desenvolvimento Rural; Ministério do Desenvolvimento Agrário. São Paulo: DIEESE; NEAD; MDA.

Filgueiras, Luiz. 2013. A natureza do atual padrão de desenvolvimento brasileiro e o processo de desindustrialização. In Novas interpretações desenvolvimentistas, edited by Inez Silvia Batista Castro, E-papers, 532p. Rio de Janeiro: Centro Internacional Celso Furtado.

Filgueiras, Luiz, and Reinaldo Gonçalves. 2007. A economia política do governo Lula. Rio de Janeiro: Contraponto.

Fine, Ben, and Alfredo Saad-Filho. 2016. Marx's Capital. Sixth ed. London: Pluto Press. 
Gonçalves, Reinaldo. 2012. "Governo Lula e o nacional- desenvolvimentismo às avessas." Revista da Sociedade Brasileira de Economia Política 31: 5-30.

Hunter, Wendy, and Timothy J. Power. 2007. "Rewarding Lula: Executive Power, Social Policy, and the Brazilian Elections of 2006." Latin American Politics and Society 49 (1): 1-30.

Kitching, Gavin. 1989. Development and Underdevelopment in Historical Perspective: Populism, Nationalism, and Industrialization. London: Routledge.

Laclau, E. 1977. Politics and Ideology in Marxist Theory: Capitalism, Fascism, Populism. London: NLB.

Laclau, E. 2005. Populism: What's in a name? In Populism and the Mirror of Democracy, edited by Francisco Panizza, 32-49. London: Verso.

Loureiro, Pedro Mendes. 2019. "Class Inequality and Capital Accumulation in Brazil, 1992-2013." Cambridge Journal of Economics, 1-26. Advance online publication. doi:10.1093/cje/bez030.

Mafort, Kelli Cristine de Oliveira. 2018. "Reestruturação produtiva no campo e os processos de trabalho nos assentamentos de reforma agrária do Estado de São Paulo." Doutorado, Programa de Pós- Graduação em Ciências Sociais, Faculdade de Ciências e Letras UNESP.

Marx, Karl. 1992 [1867]. Capital: A Critique of Political Economy. Volume I: The Process of Capitalist Production. Ernest Mandel (Introduction), transl. by Ben Fowkes. Harmondsworth: Penguin. 1990-1992, 1152p.

Mitidiero Junior, Marco Antonio, ed. 2018. "Dossiê Michel Temer e a Questão Agrária." OKARA: Geografia em debate 12 (2). http://www.periodicos.ufpb.br/ojs2/index.php/okara/issue/view/2129.

Morais, Lecio, and Alfredo Saad-Filho. 2011. "Da economia política à política econômica: o novodesenvolvimentismo e o governo Lula." Revista de Economia Política 31 (4): 507-527.

Oliveira, Francisco de. 2006. "Lula in the Labyrinth." New Left Review 42: 5-22.

Oliveira, Francisco de. 2007. Hegemonia às avessas. Piauí. Accessed 22 November 2017. https://piaui. folha.uol.com.br/materia/hegemonia-as-avessas/.

Oliveira, Francisco de. 2009. Avesso do avesso. Piauí. Accessed 22 November 2017. https://piaui.folha. uol.com.br/materia/o-avesso-do-avesso/.

Pericás, Luiz Bernardo. 2017. "Monopólios, desnacionalização e violência: a questão agrária no Brasil hoje." Margem Esquerda 29: 59-71.

Pochmann, M. 2012. Nova classe média? O trabalho na base da pirâmide social brasileira. São Paulo: Boitempo.

Saad-Filho, Alfredo. 2010. "Neoliberalism, democracy, and development policy in Brazil." Development and Society 39 (1): 1-28.

Saad-Filho, Alfredo. 2014. "Brazil: Development Strategies and Social Change From ImportSubstitution to the "Events of June"." Studies in Political Economy: A Socialist Review 94 (1): 3-29.

Saad-Filho, Alfredo, and Lecio Morais. 2018. Brazil: Neoliberalism Versus Democracy. London: Pluto Press.

Sabourin, Eric. 2007. "Que política pública para a agricultura familiar no segundo governo Lula?" Sociedade e Estado 22 (3): 715-751.

Sader, Emir, ed. 2013. 10 anos de governos pós-neoliberais no Brasil: Lula e Dilma. São Paulo, Rio de Janeiro: Boitempo, Flacso.

Safatle, Vladimir. 2018. Quando você não acerta suas contas com a história, a história te assombra. interview by Andrea Dip. Publica: agência de jornalismo investigativo. Accessed 3 November 2018. https://apublica.org/2018/10/quando-voce-nao-acerta-suas-contas-com-a-historia-a-historiate-assombra/.

Sampaio Jr., Plínio de Arruda. 2012. "Desenvolvimentismo e neodesenvolvimentismo: Tragédia e Farsa." Serviço Social \& Sociedade 112: 672-688.

Scoones, lan, Marc Edelman, Saturnino M. Borras Jr, Ruth Hall, Wendy Wolford, and Ben White. 2018. "Emancipatory rural Politics: Confronting Authoritarian Populism." Journal of Peasant Studies 45 (1): 1-20. doi:10.1080/03066150.2017.1339693.

Singer, André. 2009. "Raízes sociais e ideológicas do Lulismo." Novos Estudos, CEBRAP 85: 83-102.

Singer, André. 2013. "Os impasses do 'lulismo'." In Brasil de Fato, interview conducted by Antônio David, and Fernanda Becker. Accessed November 2017. https://www.brasildefato.com.br/node/ $11399 /$. 
Singer, André. 2015. "Cutucando onças com varas curtas: O ensaio desenvolvimentista no primeiro mandato de Dilma rousseff (2011-2014)." Novos Estudos, CEBRAP 102: 43-71.

Sitcovsky, Marcelo. 2013. "Dez anos de governo do Partido dos Trabalhadores: pós-neoliberalismo, neodesenvolvimentismo, transferência de renda e hegemonia." Revista Praia Vermelha 23 (1): 117-139.

Teixeira, Gerson. 2011. Agravamento do quadro de concentração da terra no Brasil? In Boletim DALUTA. http://www2.fct.unesp.br/nera/artigodomes/7artigodomes_2011.pdf.

Vergara-Camus, Leandro, and Cristóbal Kay. 2017. “The Agrarian Political Economy of Left-Wing Governments in Latin America: Agribusiness, Peasants, and the Limits of NeoDevelopmentalism." Journal of Agrarian Change 17: 415-437.

Weyland, Kurt. 2001. "Clarifying a Contested Concept: Populism in the Study of Latin American Politics." Comparative Politics 34 (1): 1-22.

Wood, Ellen Meiksins. 1995. Democracy Against Capitalism: Reviewing Historical Materialism. Cambridge: Cambridge University Press.

Daniela Andrade is a PhD researcher at the International Institute of Social Studies (ISS) in The Hague, the Netherlands. Her research interests include the political economy of agriculture and agrarian change from a macro perspective (especially in Brazil and Mozambique). 